\title{
Effect of Alginate Concentrations on Characteristics of Lactobacillus acidophilus and Their Viability
}

\section{Debby M. Sumanti ${ }^{1}$, Indira Lanti Kayaputrii ${ }^{1}$ In-in Hanidah ${ }^{1}$, Een Sukarminah ${ }^{1}$, and Michelle Monique Pakel²}

${ }^{1}$ Faculty Member of Food Industrial Technology Department Padjadjaran University

${ }^{2}$ Alumnus of Food Industrial Technology Department Padjadjaran University

\section{Abstract}

Lactobacillus acidophilus, a probiotic bacterium, is important bacteria for establishing a balanced intestinal microflora. The number of probiotic bacteria that must be consumed to get the benefits is about $\geq 10^{7} \mathrm{CFU} / \mathrm{g}$. Viability of L. acidophilus is generally low due to environmental conditions, storage and processing. Therefore, it is essential to maintain the number of bacteria, including the use of coating material

Corresponding Author: Debby M. Sumanti debby@gmail.com

Received: 28 July 2017

Accepted: 14 September 2017

Published: 23 November 2017

Publishing services provided by Knowledge E

(c) Debby M. Sumanti

et al. This article is distributed under the terms of the

Creative Commons Attributior

License, which permits

unrestricted use and

redistribution provided that

the original author and source are credited.

Selection and Peer-review under the responsibility of the ICSAFS Conference Committee. followed by freeze drying. This microencapsulation method study aimed to determine the exact concentration of alginate in order to improve viability and attain best microcapsule characteristics by freeze drying method. A completely randomized design with 4 treatments and 4 replications was used. Alginate concentrations used were $1 \%, 2 \%, 3 \%$, and $4 \%(w / v)$. They showed that no significantly difference on cell viability but a significant by different moisture content and yield of microcapsules. Treatment with $4 \%$ concentration was the best on generating microcapsules $L$. acidophilus with viability of $97.89 \%$, water content of $3.43 \%$, yield of $16.32 \%$. It could also reduce resistance to $\mathrm{pH} 2.0$ and bile salt $0.5 \%$ respectively $4.90 \mathrm{log} \mathrm{cfu} / \mathrm{g}$ and $4.38 \% \log \mathrm{cfu} / \mathrm{g}$ of total initial bacteria $4.99 \log \mathrm{cfu} / \mathrm{g}$.

Keywords: alginate, microencapsulation, Lactobacillus acidophilus, viability and characteristics.

\section{Introduction}

Lifestyle of the people is beginning to realize the importance of health causes food necessities not only limited to the nutritional needs with a delicious flavour, but also be expected to work on maintaining health of body. These kinds of food products are usually called functional food [1].

Functional food is a processed food containing one or more food components which are based on scientific studies, have certain physiological functions beyond basic functions, proved to be harmless, and beneficial to health. Food products are mostly being 
developed as functional foods include probiotic products. Probiotic product is a product containing live bacteria with the aim of providing beneficial effects for people who consume by improving the balance of intestinal microflora.

Lactic Acid Bacteria (LAB) is classified as probiotic bacteria if it has probiotic properties such as the ability to survive in the gastrointestinal tract and provide a beneficial influence on its host. LAB has an important role in people's lives not only through its involvement in the fermentation of food but also on its ability to grow in the gastrointestinal tract [2]. Some strains of LAB are potential as agent probiotics such Lactobacillus acidophilus because of its ability to inhibit the growth of pathogenic enteric bacteria.

Previous study described the importance of the viability of probiotics, i.e. the number of live microbes should be enough to give a positive effect on health and able to colonize thus achieving the required number for a certain time [3]. According to the International Dairy Federation (IDF), to gain benefit from its physiological function, the amount consumed probiotic bacteria should be $\geq 10^{7} \mathrm{CFU} / \mathrm{g}$. Viability of probiotic bacteria (the number of active cells in 1 gram or $\mathrm{ml}$ of product) is a critical point for probiotic products. Probiotic bacteria must have a high resistance during processing and storage.

Processing and storage can lead a decrease on viability of probiotic bacteria. The growth of $L$. acidophilus on logarithmic phase stored for 40 days in milk at a temperature of $7^{\circ} \mathrm{C}$ experiences decrease from 7.6 logs to 6.5 logs. One way to maintain the number of bacterial cells during storage and processing is microencapsulation method because the method is able to protect the probiotic bacteria cells from damage caused by processing, drying application, storage process, as well as low $\mathrm{pH}$ and bile salt produced by gastrointestinal [4]. Microencapsulation technique that is often used in drying the probiotic bacteria is freeze drying.

Freeze drying is one of microencapsulation method which is generally used to preserve the culture and produce starter concentrates. The drying process takes place by avoiding the liquid phase through sublimation that is direct conversion from ice into vapour. Freeze drying process requires a coating material to protect the bacterial cells during freezing and drying.

The coating material that is commonly used for microencapsulation is obtained from various types of carbohydrates, gum, and proteins such as starch, alginate, Arabic gum, gelatin, carrageenan, albumin and casein. The coating material used is a combination of protein and carbohydrates in which alginate as a source of carbohydrates and skim milk as a protein source. Best alginate composition is $3 \%$ based on previous research $[5,6]$ the use of skim milk coating with a concentration of $10 \%$ was able to maintain cell viability well after freeze drying. Based on that explanation, it is needed to do research 
on the effect of alginate concentrations in 10\% skim milk as a coating material on the characteristics and viability of microencapsulated biomass $L$. acidophilus.

\section{Materials and Method}

\subsection{Tools}

The tools used in this study were laminar air flow, refrigerator, oven, refrigerated centrifuge, incubators, freeze dryer Christ Alpha 1-4 LD plus, autoclave, water bath, spectrophotometers and microscopes.

\subsection{Materials}

Materials used in these experiments were pure isolate of Lactobacillus acidophilus obtained from the Laboratory of Biotechnology, Agency for the Assessment and Application of Technology (BPPT) Serpong, alginate, skim milk, MRS (deMan Rogosa Sharpe) Agar (Oxoid), MRS Broth (Oxoid), physiological $\mathrm{NaCl} 0.85 \%$, distilled water, $\mathrm{BaCl}_{2} 1 \%, \mathrm{H}_{2} \mathrm{SO}_{4} 1 \%$, violet crystal, lugol, safranin, alcohol $95 \%$, alcohol $70 \%$ and $\mathrm{H}_{2} \mathrm{O}_{2}$.

\subsection{Method}

The method used was experimental method by using a completely randomized design (CRD). The experiment consisted of four treatments with four replications. The treatments tested were:

$$
\begin{aligned}
& A=\text { Alginate concentration of } 1 \%(w / w) \\
& B=\text { Alginate concentration of } 2 \%(w / w) \\
& C=\text { Alginate concentration of } 3 \%(w / w) \\
& D=\text { Alginate concentration of } 4 \%(w / w)
\end{aligned}
$$

\subsection{Implementation}

In this research, the morphology and physiological characteristics of pure culture, biomass and microencapsulated of bacteria $L$. acidophilus were studied to ensure that there is no changes during the manufacturing process of biomass and freeze drying. Furthermore, the manufacture of biomass and microencapsulation of L. acidophilus through the freeze drying process that referred to other previous study were studied [7]. The parameters observed from microcapsule of L. acidophilus were cell viability, water content and yield of microcapsule $L$. acidophilus biomass. The best treatment 
was based on a statistical test followed by observation of the resistance to $\mathrm{pH} 2.0$ and $0.5 \%$ bile salt of microcapsules L. acidophilus biomass.

\subsection{Morphology and Physiology Characteristics of Pure Culture, Biomass, and Microcapsules}

\subsection{Gram Staining [8]}

Bacterial isolates placed above the glass object. Violet crystal was dripped above smear bacteria then allowed to stand for 30 seconds. Object glass was rinsed with distilled water until the colour disappeared and dried. Drop iodine and let stand for 1 minute, then rinsed again using distilled water until the colour disappeared. Spray alcohol 95\% and then let stand for 30 seconds, rinse the glass object with distilled water. Safranin last dripped and allowed to stand for 1 minute. Object glass was rinsed with distilled water until the colour disappeared. Bacterial morphology was observed using a microscope.

\subsection{Catalase Test [8]}

One dose of bacterial isolates was inoculated on object glass, then dropped $3 \% \mathrm{H}_{2} \mathrm{O}_{2}$. If the gas bubbles generated, bacteria was stated as positive catalase, but if not the bacteria was stated as negative catalase.

\subsection{Motility Test [9]}

Bacterial isolates of 1 ose (using straight ose) were stabbed vertically into MRS agar media upright a semi-solid (agar concentration on the MRS lowered to $0.5 \%$ ). Media were incubated at $37^{\circ} \mathrm{C}$ for 48 hours. If isolates only grew around the puncture, socalled non-motile bacteria, but if isolates grew spreads, stated as motile bacteria.

\subsection{Gas Production Test [9]}

Bacterial isolates were grown in $5 \mathrm{ml}$ MRS broth media which were given the inverted Durham tube. Media were incubated at $37^{\circ} \mathrm{C}$ for 48 hours. If there was air bubble in Durham tube, gas production was positive, but if the tube Durham entraps no air bubbles, gas production was negative. 


\subsection{Manufacture of biomass [7]}

L. acidophilus culture was shed using sterile distilled water (Autoclave $\mathrm{T} 121^{\circ} \mathrm{C}, \mathrm{t} 15$ second), then checking the turbidity according to Mc Farlan 3 at a wavelength $=600$ $\mathrm{nm}$, the absorbance \pm 0616 (equivalent to the number of colonies of bacteria $3.0 \times$ $10^{8} \mathrm{cfu} / \mathrm{ml}$ ) using a spectrophotometer. Culture that had been made was inoculated into MRS broth in the ratio 1: 6 . The media were incubated at $37^{\circ} \mathrm{C}$ for 12 hours. Biomass harvesting was done by centrifugation at $4^{\circ} \mathrm{C}$ with speed of $3500 \mathrm{rpm}$ for 20 minutes. 1 $\mathrm{ml}$ of biomass was used for the viability test before the freeze drying.

\subsection{Manufacture of Probiotics Microencapsulation with Freeze Drying [7]}

Biomass of bacteria L. acidophilus was added by coating material skim milk $10 \%$ and alginate with various concentrations ratio namely $1 \%, 2 \%, 3 \%$ and $4 \%$, dissolved in sterile distilled water, by comparison between coating and biomass 7: 3. The coating materials and biomass homogenized using a vortex mixer and then put into a sterile beaker glass and frozen in freezer with temperature of $-23^{\circ} \mathrm{C}$ for 24 hours. Furthermore, the process of freeze drying at temperature of $-50^{\circ} \mathrm{C}$ for 24 hours was taken.

\subsection{Test of Bacteria Cell Viability [6]}

Test of bacteria L. acidophilus cell viability before and after the freeze drying process was done in MRS agar media by pouring method with a series of dilutions using physiological $\mathrm{NaCl}$ diluent solution. A total of $1 \mathrm{ml}$ of the biomass before dried and $1 \mathrm{~g}$ of dried culture, subsequently diluted to $10^{-10}$ dilution, took 1 to $3 \mathrm{ml}$ last dilution (dilution $10^{-8}, 10^{-9}, 10^{-10}$ ) and put into a sterile petri dish, added sterile MRS agar media until the base dish was covered by media. Mixing until homogeneous the suspension with the media, incubating at $37^{\circ} \mathrm{C}$ for 48 hours. Calculating the viability of probiotic bacteria based on the ratio of the number of bacteria per gram after and before the encapsulation process and stated in per cent (\%).

\subsection{Test of Microcapsules Moisture Content by Thermogravimetric}

A total of $0.5 \mathrm{~g}$ of bacterial cell microcapsule L. acidophillus inserted into the dish and then put into an oven at $105^{\circ} \mathrm{C}$ for 5 hours. Then the dish was cooled in a desiccator for 15 minutes and weighed. The dish containing the sample put again into the oven 
for 30 minutes, the dish was cooled again in a desiccator for 15 minutes and weighed. This stage was repeated until a constant weight was reached.

\subsection{Test of Microcapsule Yield}

Yield was calculated by comparing the weight of microencapsulated probiotic bacteria with biomass of probiotic bacteria and coating used.

\subsection{Resistance to $\mathrm{pH} 2.0[6]$}

Testing of $\mathrm{pH} 2.0$ was carried out using MRS broth medium which was adjusted to $\mathrm{pH} 2.0$ using $\mathrm{HCl} 37 \%$. Culture that had been refreshed in MRS broth for 24 hours was inoculated into MRS broth control and MRS broth $\mathrm{pH}$ 2.0, and then incubated at temperature of $37^{\circ} \mathrm{C}$ for $\mathrm{o}$ and 5 hours. After incubation conducted, dish was counted on MRS agar using pouring method and incubated at $37^{\circ} \mathrm{C}$ for 48 hours. Resistance to $\mathrm{pH} 2.0$ was calculated based on the log margin of the number of colonies that grew on the incubation time of $o$ and 5 hours.

\subsection{Resistance to Bile Salt 0.5\% [6]}

Tests on a $0.5 \%$ bile salt was conducted using MRS broth medium. Culture of $1 \mathrm{ml}$ which was refreshed in MRS broth for 24 hours was put in $9 \mathrm{~mL}$ of MRS broth containing $0.5 \%$ bile salt then incubated at $37^{\circ} \mathrm{C}$ for 0 and 5 hours. After incubation conducted, dish was counted on MRS agar by pouring method and incubated at $37^{\circ} \mathrm{C}$ for 48 hours. Resistance to bile salt was calculated based on the log margin of the number of colonies that grew on the incubation time of $o$ and 5 hours.

\section{Result and Discussion}

\subsection{Morphological Characteristic of L. acidophilus}

The bacteria observed in pure culture, biomass, and microcapsule showed grampositive, rod-shaped with a size of $2.88-3.28 \mu \mathrm{m}$, catalase negative, non-motile, and homo fermentative. Results of morphology verification of bacteria $L$. acidophilus in pure culture, biomass, and microcapsule showed that the morphological and physiological characteristics of the bacterial cells were observed in pure culture, biomass, and microcapsule unchanged and in conformity with the characteristics of L. acidophilus. 
TABLE 1: Characteristic of L. acidophilus in Pure Culture Biomass and Microcapsule.

\begin{tabular}{|c|c|c|c|}
\hline Criteria & Pure Culture & Biomass & $\begin{array}{c}\text { Micro } \\
\text { capsule }\end{array}$ \\
\hline Gram Staining & Positive & Positive & Positive \\
\hline Cell Form & Rod & Rod & Rod \\
\hline Catalase Test & Negative & Negative & Negative \\
\hline Motility Test & Non motile & Non motile & Non motile \\
\hline Gas Production Test & Negative & Negative & Negative \\
\hline $\begin{array}{l}\text { Microscope Image Magnifi- } \\
\text { cation of } 1000 x\end{array}$ & $=22^{8}{ }^{\prime}$ & $328+9$ & $\begin{array}{l}5-4 \\
758 \\
-28\end{array}$ \\
\hline
\end{tabular}

TABLE 2: Effect of Alginate Concentration on Viability of Microencapsulated L. acidophilus.

$\begin{array}{ll}\text { Alginate Concentration (w/v) } & \text { Viability Average (\% d.b) } \\ \begin{array}{ll}A=\text { Alginate } 1 \% & 96.30 \mathrm{a} \\ B=\text { Alginate } 2 \% & 96.71 \mathrm{a} \\ \text { C = Alginate } \% & 96.92 \mathrm{a} \\ \text { D = Alginate 4\% } & 97.89 \mathrm{a}\end{array}\end{array}$

L. acidophilus included in gram-positive bacteria, non-motile, rod-shaped with a size of 0.6 - 0.9 until $1.0-6.0 \mu \mathrm{m}$, single cell, in pairs, or forming short chains [10], catalase negative [8], and homo fermentative [11]. The encapsulation process is successful if the encapsulated material has relatively similar physiological characteristics toward pre-encapsulated [5].

\subsection{Viability}

Based on statistical analysis, additional of alginate concentrations treatment provided not significantly different effect on the viability of cells $L$. acidophilus microcapsules. The test results of bacteria cell $L$. acidophilus microcapsules viability can be seen in Table 2.

Viability of bacteria is a bacterial live survival under certain environmental conditions. The addition of alginate $1-4 \%$ by freeze drying method could maintain the viability of L. acidophilus microcapsules biomass up to $97.89 \%$, this was due to properties of alginate which is easy to form gel matrix, causing the viscosity to rise. In 
TABle 3: Effect of Alginate Concentration on Moisture Content of L. acidophilus Microcapsules.

$\begin{array}{lc}\text { Alginate Concentration (w/v) } & \text { Moisture Content Average(\% d.b) } \\ \begin{array}{ll}\text { A }=\text { Alginate } 1 \% & 4.58 \mathrm{a} \\ \mathrm{B}=\text { Alginate } 2 \% & 3.63 \mathrm{a} \\ \text { C }=\text { Alginate } 3 \% & 3.47 \mathrm{~b} \\ \text { D = Alginate 4\% } & 3.43 \mathrm{~b}\end{array}\end{array}$

the higher viscosity, layer that surrounds the "core material" will be formed faster, so that the "core material" is immediately protected. Therefore the more the alginate concentration increase, the more cells are protected so it can improve the viability of microcapsules of bacteria L. acidophilus biomass.

The important factor to maintain the viability of bacterial cells in the microencapsulation process is the selection of coating material that will protect the core material. The coating material used in this study was 10\% skim milk and various concentrations of alginate. Optimum efficiency can be generated from a matrix of proteins and carbohydrates as microcapsules bacterial cells of L. acidophilus [12]. Skim milk as a coating also affects the viability of microcapsules resulted. This is because the protein in skim milk can provide protection in cells during the microcapsules process. Two layers encapsulation that uses skim milk and alginate as the protector will produce more cells than one layer encapsulation or using alginate alone.

The highest viability was obtained in alginate concentration of $4 \%$ in $10 \%$ skim milk ie $97.89 \%$. This result is in line with another research [13], which stated that the viability of microencapsulated probiotic bacteria with freeze drying method can be retained up to $98 \%$.

\subsection{Water Content of Biomass Bacteria L. acidophilus Microcapsules}

Based on statistical analysis, treatment of alginate concentration addition gave a significantly different effect on water content. The test result of water content of microencapsulated $L$. acidophilus can be seen in Table 3.

Based on Table 3, the water content of microencapsulated $L$. acidophilus cells of treatment $A$ was not significantly different with treatment $B$, but it was significantly different with treatment $\mathrm{C}$ and $\mathrm{D}$. The higher alginate concentration added, the lower microcapsules water content, this is due to the function of alginate which can bind water. The increase in coating material concentration will increase the total solids 
TABLE 4: Effect of Alginate Concentration on L. acidophilus Microcapsules Yield.

\begin{tabular}{lc} 
Concentration Ratio $(w / v)$ & Yield Average (\% db) \\
\hline$A=$ Alginate $1 \%$ & $14.73 b$ \\
\hline$B=$ Alginate $2 \%$ & $15.05 b$ \\
\hline C = Alginate 3\% & $16.11 a$ \\
\hline$D=$ Alginate 4\% & $16.32 a$
\end{tabular}

content in the solution, which means a decrease of water concentration in the solution, consequently after the drying, water content in the materials will be lower [14].

At the freezing stage, protein is absorbed by the ice, and then during the drying stage the ice crystals will disappears to leave cavities on the surface and there will be an increase in cavities pores so that the rate of sublimation of ice goes high, thus the water content of the product is getting low [13]. Freeze drying method can eliminate the water content to below $10 \%$. This is suitable with the results obtained that the water content of microencapsulated L. acidophilus ranged between 3.43\%-4.58\% $(w / w)$.

Freeze drying method can generate microencapsulated probiotics with water content of $3 \%-8 \%$. The water content of the dried material through freeze drying method can account for less than $2 \%$ [15]. An increase in the concentration of the coating material will increase the total solids content in the solution, which means a decrease in water concentration in the solution, so that after the drying, water content in the materials will be smaller [14]. The higher the water content of the microcapsules, the shorter the shelf life will be. Other microorganisms can also grow because of the availability of water to live and breed.

\subsection{Yield of Biomass Bacteria L. acidophilus Microcapsules}

Based on statistical analysis, addition of maltodextrin concentration treatment gave a significantly different effect on yield of $L$. acidophilus cells microcapsules. The test results of $L$. acidophilus cells microcapsules yield can be seen in Table 4 .

Based on Table 4 , the yield of microcapsules of $L$. acidophilus cells from treatment A was not significantly different with treatment $B$, but significantly different with treatment $C$ and $D$. The higher the alginate concentration, the more yield produced, due to increase on resulted total solids material. The use of skim milk coating material with higher alginate concentration may increase the viscosity of the material, since the nature of alginate which can form gel matrix in consequence increase the yield. 
Increase in yield is accordance with the concentration of alginate as the added coating material can increase the total solids in the dried material. The higher the viscosity, the faster the forming of coating that surrounds the core material (L. plantarum cell), so that the core material will be protected immediately thereby yield of microcapsules will be greater and this is in line with increasing of bacteria viability.

\subsection{Resistance on pH 2.0 and Bile Salt 0.5}

The treatment alginate concentration of $4 \%$ in $10 \%$ skim milk gave the best results which generated cell viability of $L$. acidophilus microcapsules as $97.89 \%$. Further it was tested on resistance to $\mathrm{pH} 2.0$ and bile salt 0.5 . The resistance of bacteria $L$. acidophilus microcapsules was indicated by the decline in total bacteria L. acidophilus after incubation (o hours) in MRS broth media containing acid for 5 hours.

Results of resistance to $\mathrm{pH} 2.0$ for the control was $4.99 \mathrm{log} \mathrm{cfu} / \mathrm{g}$, while bacteria $L$. acidophilus microcapsules of $4.90 \mathrm{log} \mathrm{cfu} / \mathrm{g}$. The addition of coating material skim milk $10 \%$ and $4 \%$ alginate could maintain resistance L. acidophilus microcapsules to $\mathrm{pH} 2.0$. Value of $\mathrm{pH} 2.0$ can cause damage on bacterial culture, this was shown from a decrease in the number of cells after incubation for 5 hours. The presence of acid inhibition of the bacterial cells occurs through the cell membrane damage, and the influence of enzyme denaturation. Moreover bacterial cells have suffered stress because of the influence of drying and freezing.

Resistance of bacteria L. acidophilus microcapsules to bile salt $0.5 \%$ was indicated by the decline in total bacterial L. acidophilus after incubation (o hours) in MRS broth media containing acid for 5 hours. Results of resistance to $\mathrm{pH} 2.0$ for the controls was 4.99 $\log \mathrm{cfu} / \mathrm{g}$, whereas the L. acidophilus microcapsules at $4.38 \mathrm{log} \mathrm{cfu} / \mathrm{g}$. The addition of coating material skim milk $10 \%$ and $4 \%$ alginate microcapsules could maintain $L$. acidophilus resistance to bile salt $0.5 \%$.

The decrease in number of probiotic bacteria due to bile salt $0.5 \%$ apparently caused by cell leakage although lyse had not appeared yet. Alginate which contains polysaccharide component could be expected to help draw up the cell walls of gram-positive bacteria, thus it's resistant to bile salt.

\section{Conclusion}

Effect of alginate concentrations in microencapsulated bacteria $L$. acidophilus was not significantly different on cell viability but significantly different on water content and yield of bacteria L. acidophilus microcapsules. The treatment of alginate concentration 
of $4 \%$ in $10 \%$ skim milk was the best treatment to generate L. acidophilus microcapsules with viability of $97.89 \%$, water content of $3.43 \%$, yield of $16.32 \%$, could reduce resistance to $\mathrm{pH} 2.0$ and bile salt $0.5 \%$ respectively $4.90 \mathrm{log} \mathrm{cfu} / \mathrm{g}$ and $4.38 \% \mathrm{log} \mathrm{cfu} / \mathrm{g}$ of total initial bacterial $4.99 \log \mathrm{cfu} / \mathrm{g}$.

\section{Acknowledgement}

Researchers were very grateful to the Ministry of Research, Technology and Higher Education, Directorate of Research and Community Service that had funded this research through PUPT Program Year 2015.

\section{References}

[1] Susanto, A. 2012. Peranan Bakteri Asam Laktat (BAL) pada Pengolahan Makanan Fermentasi. Available at: https://anthosusantho.wordpress.com/2012/03/22/ peranan-bakteri-asam-laktat-bal-pada-pengolahan-makanan-fermentasi/ (diakses 12 Maret 2015)

[2] Harmayani, E., Ngatirah, E. S. Rahayu, dan T. Utami. 2001. Ketahanan dan viabilitas probiotik bakteri asam laktat selama proses pembuatan kultur kering dengan metode freeze dan spray drying. Jurnal Teknol. dan Industri Pangan. 2:126-132

[3] Banyuaji, A., E.S. Rahayu, dan T. Utami. 2009. Viabilitas Lactobacillus acidophilus SNP 2 dalam kapsul dan aplikasinya dalam es krim. Jurnal Agritech. 29:171-176.

[4] Zuidam, N.J. dan E. Shimoni. 2010. Overview of microencapsulates for use in food products or processes and methods to make them in Zuidam NJ dan Nedovic VA (eds). Encapsulation Technologies for Active Food Ingredients and Food Processing. London: Springer.

[5] Triana, E., E. Yulianto, dan N. Nurhidayat. 2006. Uji viabilitas Loctobacillus sp. Mar 8 terenkapsulasi. Jurnal Biodiversitas. 7:114-177.

[6] Puspawati, N. N., L. Nuraida, dan D. R. Adawiyah. 2010. Penggunaan berbagai jenis bahan pelindung untuk mempertahankan viabilitas bakteri asam laktat yang di isolasi dari air susu ibu pada proses pengeringan beku. J. Teknol. dan Industri Pangan. 21:59-65.

[7] Rizqiati, H., B. S. L. Jenie, N. Nurhidayat, dan C. C. Nurwitri. 2009. Karakteristik mikrokapsul probiotik Lactobacillus plantarum yang dienkapsulasi dengan susu skim dan gum arab. Journal Animal Production. 10(3):179-187.

[8] Pyar, H. dan K. K. Peh. 2014. Characterization and identification of lactobacillus acidophilus using rapid identification system. International Journal of Pharmacy and Pharmaceutical Sciences. 6(1): 189-193. 
[9] Rahayu, E.S. dan S. Margino. 1997. Bakteri Asam Laktat: Isolasi dan Identifikasi. PAU Pangan dan Gizi. Universitas Gajah Mada. Yogyakarta.

[10] Breed, R. S., E. G. D. Murray, dan N. R. Smith. 1957. Bergey's Manual of Determinative Bacteriology Seventh Edition. The Williiam and Wilkins Company, USA.

[11] Curran, H.R., L.A. Rogers, and E. O. Whittier. 1932. The Distinguishing Characteristics of Lactobacillus acidophilus. Research Laboratories, Bureau of Dairy Industry, United States.

[12] Lin, C.C., S. Y. Lin, dan L. S. Hwang. 1995. Microencapsulation of Squid Oil with Hydrophilic Macromolecules for Oxidative and Thermal Stabilization. J. Food Sci.6o 1: 36-39.

[13] Dolly, P., A. Anishaparphin, G. S. Joseph, dan A. Khrisnan. 2011. Microencapsulation of Lactobacillus plantorum by spray freeze drying method and evaluation of survival in simulated gastrointestinal conditions. Mysore 570 020, India.

[14] Sadikin. 1993. Sumber Daya Nabati 1 Kacang-Kacangan. Gramedia Pustaka. Jakarta.

[15] Hermanza, A. 2013. Proses Vacuum Freeze Drying Ubur-Ubur dengan Menggunakan Udara Lingkungan. [Thesis]. Fakultas Teknik Mesin, Universitas Indonesia, Depok. 